\title{
THE HERMENEUTICS OF THE HAFTAROT
}

\section{Gregory Goswell}

\begin{abstract}
Summary
The excerpts from the Prophetic Books selected to match the weekly public reading of the Torah in the synagogue were not chosen in a haphazard manner. They are supported by verbal and thematic links with the Torah reading and amount to a theologically serious reading of sacred Scripture. This pairing of biblical texts reflects an implied hermeneutic namely a way of interpreting both Law and Prophets, that has its roots in the established patterns of early Jewish preaching and teaching. The survey provided by this article demonstrates that a consideration of the paired readings is of great value to the Christian reader of the Old Testament.
\end{abstract}

\section{Introduction}

The Haftarot (sing. Haftarah) are the selections from the Prophets recited publicly in the synagogue on sabbaths, festivals and certain fast days after the set portion from the Torah (or Parashah). ${ }^{1}$ For the Jews, the canonical section 'Prophets' covers the books of Joshua, Judges, Samuel and Kings, as well as what Christians consider as the Prophetic Books proper, namely Isaiah, Jeremiah, Ezekiel and the Twelve (the Minor Prophets), so that it is for the Jews an eight-book canonical section. The pairing and matching of Torah and Prophetic readings brings the one text into relationship with the other. When they are conjoined in this fashion, texts transform one another, given the natural expectation of the hearer/reader that the juxtaposed texts are related in

1 On the possible origins of the public recitation of the Torah, see Michael Fishbane, 'Haftarot', in The JPS Bible Commentary (Philadelphia: The Jewish Publication Society, 2002): xx-xxiii. The survey of the Haftarot provided in this article is informed at many points by the insights of Fishbane. 
some significant way. In this case, the Prophetic text provides what is in effect a commentary on the Torah reading, for the reading from the Prophets is subsequent to the Torah reading and the Torah readings follow a continuous sequence, whereas the Haftarot are discontinuous and selective and are chosen because of the perceived association with or relevance to the particular Torah portion. In this way, the Haftarot open a window on how certain Jews in the past made sense of the Five Books of Moses. The relevance of a study of the Haftarot is that it can help us to better understand both the Old Testament and certain communities of Judaism. As well, it is important for our Christian tradition of interpretation to be informed (and challenged) by other traditions that reverence the same sacred text. Such a study comes under the heading of 'Intertextuality': namely the reading of texts in relation to other texts - yet in this case within the confines of the canonical boundaries.

With regard to what Prophetic Books are drawn upon for the Prophetic readings to match the 54 weekly sabbath readings of the Torah, note the following tabulation:

$\begin{array}{ll}\text { Joshua } \times 1 & \text { Isaiah 1-39 ×3 } \\ \text { Judges } \times 4 & \text { Isaiah 40-66 ×11 } \\ 1 \text { Samuel } \times 1 & \text { Jeremiah } \times 8 \\ 2 \text { Samuel } \times 2 & \text { Ezekiel } \times 7 \\ 1 \text { Kings } \times 10 & \text { Hosea } \times 3 \\ 2 \text { Kings } \times 3 & \text { Amos } \times 2 \\ & \text { Obadiah } \times 1 \\ & \text { Micah } \times 1 \\ & \text { Zechariah } \times 1 \\ & \text { Malachi } \times 1\end{array}$

Most scholars regard the one-year cycle of 53 (or 54) reading portions (or Parashiyyot) from the Torah as a Babylonian practice that spread through the Jewish Diaspora after the transfer of the hegemony of the Babylonian academy to Spain in the eleventh and twelfth centuries, and especially because of the authoritative backing of Maimonides. A notable exception was the synagogue in Egypt (Cairo) that was still clinging to the triennial cycle in the thirteenth century. The annual cycle supplanted the so-called 'triennial cycle' of the Jewish communities in Palestine. Really it was a three and a half year cycle: in 
fact, a double reading cycle of seven years, ${ }^{2}$ based on a rabbinical understanding of Deuteronomy 31:10-13. ${ }^{3}$ The two cycles were probably historically interdependent (in the Amoraic period), though their exact connection is now shrouded in mystery.

\section{Overall Emphases in the Haftarot}

In the triennial list of 154 Sedarim (sing. Seder), nearly half the readings are from Isaiah, and roughly two-thirds of these from Isaiah 40-66, often with a obvious eschatological dimension. ${ }^{4}$ There is usually a strong verbal link between the opening verse or two of the Torah lesson and the opening of the Prophetic selection. The annual cycle has its roots in the older multi-year cycles, and its choice of Prophetic readings may be (in part) a derivative selection of all the available Haftarot in those cycles. In the annual cycle, which is what I will focus upon in this article, ${ }^{5}$ the largest cluster of Prophetic readings come from Isaiah (14), and a smaller number from Jeremiah (8), Ezekiel (7) and the Twelve (9), with these together making up twothirds of the whole. The annual cycle (compared to the triennial cycle) has a smaller proportion of readings from the later chapters of Isaiah and is less eschatological in emphasis. With regard to readings from the

2 b. Meg. 29 b.

3 Fishbane, 'Haftarot': xxiii; Louis Finkelstein, 'The Prophetic Readings according to Palestinian, Byzantine and Karaite Rites', HUCA 17 (1942-43): 423-26. It would have taken about 172 sabbaths to complete the cycle of 154 Torah readings, taking into consideration the extra readings because of festivals, Hanukkah, New Moons and four special sabbaths. For the (Palestinian) triennial list of 154 Sedarim, see Charles Perrot, 'The Reading of the Bible in the Ancient Synagogue', in Mikra: Text, Translation, Reading and Interpretation of the Hebrew Bible in Ancient Judaism and Early Christianity, ed. M. J. Mulder (Assen/Maastricht: Van Gorcum; Philadelphia: Fortress Press, 1988): 137-59, esp. 141-43. For ancient Palestinian practices, see Adolf Büchler, 'The Reading of the Law and the Prophets in a Triennial Cycle,' JQR NS 5 (1893): 420-68, in The Jewish Quarterly Review: The Original Series as Published in England (Reprinted; New York: KTAV, 1966).

4 See Ben Zion Wacholder, 'Prolegomenon,' in Jacob Mann, The Bible as Read and Preached in the Old Synagogue: A Study in the Cycles of Readings from Torah and Prophets, as well as from Psalms and in the Structure of Midrashim Homilies: Volume 1, ed. Harry M. Orlinsky (1940; The Library of Biblical Studies; reprint New York: KTAV, 1971): xxxi-xxxiii.

5 Limitations of space require that we focus upon the weekly sabbath readings, to the exclusion of readings for special sabbaths, Days of Awe, festivals and weekday occasions. 
Former Prophets (Joshua-Kings), the 13 readings from Kings dominate.

The Haftarot of the annual cycle reflect a strong interest in historical parallels or symmetries, ${ }^{6}$ amounting to a kind of typological reading of Scripture. There is no focus on prophetic rebuke, though the two readings from Amos (2:6-3:8; 9:7-15) suggest a balance between rebuke and promise in the framing of this selection of readings from the Prophetic Books. The dominance of Isaiah 40-66 in the selection of Prophetic readings is also evidenced by the fact that the first three Haftarot are drawn from that section (Isa. 42:5-43:10; 54:1-55:5; 40:27-41:16), and as well there is a group of seven portions from Isaiah 40-66 attached to readings from Deuteronomy near the end of the cycle. In this way, readings from Isaiah 40-66 encircle the Haftarot. This suggests the perception that although both rebuke and comfort are perennially needed by God's people, the accent should be upon consolation. It is certainly the case that the Prophetic Books tend to end with consolation and hope (e.g. Isa. 40-66; Ezek. 34-48; Amos 9:1115), so that it would be tendentious to view the selection made for the Haftarot as a distortion of the message of the prophets. The New Testament itself accentuates the aspect of promise when making reference to the ministry of the prophets (e.g. Luke 1:70; 2 Cor. 1:20; 1 Pet. 1:1012).

The earliest evidence of the ancient recitation of a Prophetic selection in the synagogue is actually found in the New Testament: Luke 4:14-19 (in which only two verses are read [Isa. 61:1-2] out of a longer portion?) and Acts 13:13-41 (esp. v. 15). Neither passage, however, proves that there was at this stage a set cycle of scriptural selections from the Torah and the Prophets. ${ }^{7}$ Two other texts in the book of Acts allude to the weekly reading of the Law $(13: 27 ; 15: 21)$. This means that the theology of the Haftarot could well postdate the New Testament. It cannot be taken for granted that the interpretation implicit in the matched readings from the Torah and Prophets was current in the first century. In antiquity, the selection of the Haftarot varied greatly between Jewish communities, so that the readings discussed below are those that gradually established themselves in

6 Fishbane, 'Haftarot': xxviii-xxix.

7 Larrimore Crockett, 'Luke iv.16-30 and the Jewish Lectionary Cycle: A Word of Caution,' JJS 17 (1966): 13-46, esp. p.27; Joseph Heinemann, 'The Triennial Lectionary Cycle,' JJS 19 (1968): 41-48. 
normative Judaism. Of the different Jewish communities, I will only make mention of Ashkenazic (France-Germany) and Sephardic (Iberian) custom.

\section{Genesis}

What we discover on examination is the (often nuanced) connection between paired texts. There are resonances between the Parashah and Haftarah. These multilevel resonances indicate that the pairing of portions is not haphazard. There is some link, verbal or thematic, between the Torah and Haftarah readings. Haftarah 1 (Isa. 42:5-43:10) highlights the creation language of this Isaianic section for it corresponds to Genesis 1:1-6:8. The Haftarah actually begins on the creation theme (42:5). The connection asserts that God's works of creation and redemption are linked and that redemption is a new act of creation and aims to restore a pristine creation. ${ }^{8}$ The connection between the Parashah 2 (Gen. 6:9-11:32) and its Haftarah (Isa. 54:1-55:5) is shared references to the flood story, especially Isaiah 54:9-10. The ongoing relevance of the covenant with Noah is thereby asserted, so that at the eschaton all the covenants are fulfilled, including this one. God's choice of Abraham (Gen. 12:1-17:27) in the third Torah reading is turned into an encouragement to God's people in the matching Haftarah (Isa. 40:27-41:16), wherein God calls Israel 'the offspring of Abraham, my friend' (41:8). Both Abraham and exiled Israel are called from 'the ends of the earth ... from its farthest corners' (Mesopotamia in both cases), so that the nation is destined to recapitulate the experience of its illustrious forebear. ${ }^{9}$

The miraculous birth of Isaac and his near death are narrated in Genesis 18:1-22:24, and the corresponding Haftarah tells the story of the son born to the Shunammite with the old husband, and of her son's death and raising (2 Kgs 4:1-37). This makes the binding of Isaac, when he is nearly sacrificed and only redeemed at the last moment, into a kind of resurrection story, which is exactly how the New Testament

8 The first Palestinian Seder for Genesis $(1: 1-2: 3)$ is matched by the reading of Isa. 65:17-25, which suggests the same theological understanding (65:17: 'Behold, I create a new heavens and a new earth').

9 The Palestinian Seder 10 (Genesis 12-13) is connected to Isaiah 51, which recalls God's call of Abraham ('for when he was but one I called him') as an encouragement to Isaiah's hearers. 
writers understand it (Heb. 11:17-19; Rom. 4:17). ${ }^{10}$ This is a case where familiarity with the Haftarot (reflecting as they do certain strands of traditional Jewish interpretation) helps us to appreciate why the New Testament writers understood the biblical text they way they did. It places their exegesis into a (near-contemporary) context. The character of the God established in this Pentateuchal episode is as the God who gives life to the dead. This clears Jesus of the charge of using Scripture in an arbitrary way when he finds evidence in the Pentateuch for a resurrection doctrine (Matt. 22:31, 32; citing Exod. 3:6), for the Haftarah indicates that this is a recognised way (at least in some Jewish circles) of viewing the patriarchal narratives. God's self-revelation at the burning bush as the God of Abraham, Isaac and Jacob sums up the patriarchs' experience of God who has miraculously sustained the life of the chosen line generation by generation. It is all the more telling because it is made to Moses who has been twice delivered from death in the previous chapter (Exod. 2).

The death and replacement of Sarah and the transfer of power by Abraham to Isaac (Gen. 23:1-25:18; esp. 25:5) is thematically matched by the question of who will succeed ageing David (1 Kgs 1:1-31), and the Haftarot show an interest in finding parallels in David's life (see below). The competition and enmity between Esau and Jacob in Genesis 25:19-28:9 is picked up by Haftarah 6 (Mal. 1:1-2:7), so that a long historical struggle between two nations is the outcome. Both passages assert God's choice of Jacob/Israel in preference to Esau/Edom. The Haftarah reading of Hosea 12:13 (Eng. 12:12)-14:10 (Eng. 14:9) and the Torah reading of Genesis 28:10-32:3 (Eng. 28:10-32:2) both begin with Jacob's flight to the land of Aram, and the prophet Hosea reuses the Jacob traditions to urge treacherous Israel to repent and turn back to God. Among the Ashkenazim the eighth Torah reading (Gen. 32:4 [Eng. 3]-36:43) is again linked to Hosea (Hos. 11:7-12:12 [Eng. 11]) with its references to forefather Jacob (e.g. Hos. 12:3-4). Among the Sephardim, this Torah reading, which begins with the reunion of

10 See Jon D. Levenson, 'Resurrection in the Torah: A Second Look,' (2002 Palmer Lecture, Centre of Theological Inquiry, Princeton, NJ; 21 March 2002). Levenson views the Akedah, or 'Binding of Isaac' (Gen. 22:1-19), as another example within the patriarchal narratives of the persistent pattern of death and revival that shows the miraculous preservation the chosen line. The functional equivalence of what these stories describe is resurrection, so that the intra-biblical midrashic exegesis represented by the Haftarah is not at all far-fetched, and the New Testament writers are not guilty of eisegesis. 
Jacob with his estranged brother Esau, is matched by Obadiah 1:1-21, which condemns Edom (descended from Esau) 'for the violence done to your brother Jacob [= Israel]' (v. 10).

The crimes of the ancestors against Joseph (Gen. 37:1-40:23) are repeated in Northern Israel as exposed in the matching Haftarah 9 (Amos 2:6-3:8), e.g. 2:6: 'they sell the righteous for silver' (cf. Gen. 37:28). Perhaps Joseph with his dreams is viewed as a prophet who was ignored by his brothers, just as Amos condemns his contemporaries for seeking to silence the prophets (Amos 2:12; 3:7-8). Joseph's ability to interpret dreams (Gen. 41:1-44:17) is picked up by the story of the aftermath of Solomon's dream and the display of his God-given wisdom in a judgement scene (1 Kgs 3:15-4:1). ${ }^{11}$ Joseph's rule of Egypt (for which his wisdom fits him, see Gen. 41:38-40) thus becomes a precursor to wise Solomon's reign. In both cases it is wisdom that equips a man to exercise authority. What is more, towards the end of the Torah lesson, in the episode of the stolen cup, Joseph's special insight is again featured $(44: 4-5,15)$ and his brothers are brought before him for judgement. The selfless pleadings of Judah, who offers to take the place of 'guilty' Benjamin (though this speech is outside the scope of the Parashah), find an echo in the speech of the true mother who is willing to give up her son if only he be spared (1 Kgs 3:26). The parallels are remarkable and show the exegetical insight of the framers of the Haftarot.

Parashah 11 describes the reunion of Judah and his brothers with Joseph in Egypt (Gen. 44:18-47:27) and that is given an eschatological dimension in Ezekiel 37:15-28, the vision of the two sticks. The prophets (Ezekiel among them) looked forward to the ultimate reunion of northern and southern kingdoms. The last Genesis reading (Gen. 47:28-50:26) features the death-bed blessings and instructions of Jacob, and the Haftarah recounts the final instructions of dying David to his son Solomon (1 Kgs 2:1-12). ${ }^{12}$ The persistent focus in the

11 In contrast to the annual cycle that seems content with this historical parallel, the Haftarah for the Seder 38 in the triennial cycle (Gen. 41:38-42:17) is Isa. 11:2-16, suggesting that wise Joseph is being viewed as a messianic type. Mann suggests that the connection with the Seder is really 11:2 (The Bible as Read and Preached in the Old Synagogue: 313 ).

12 What is noticeable is how often the beginning of the Haftarah coincides with the medieval chapter division of our English Bible (e.g. Isa. 54:1; 2 Kgs 4:1; 1 Kgs 2:1), when these are not where the Sedarim commence. In each case, however, the starting point is also a Hebrew paragraph division (whether open or closed). 
Haftarot upon David and Solomon suggests that these royal figures are viewed as messianic types.

\section{Exodus}

The opening Torah reading in Exodus (Exod. 1:1-6:1) pictures the fruitfulness of Jacob's family in Egypt (1:7: 'so the land was filled with them'), and twin readings from Isaiah chosen to accompany the Torah lesson (Isa. 27:6-28:13; 29:22-23) promise a future exodus (27:13) and predict that '[Israel will] fill the whole world with fruit' $(27: 6)$. The appended verses from later in Isaiah (29:22-23) succeed in giving a more optimistic conclusion to the Haftarah, for most of the material in these chapters of Isaiah is heavily critical of the nation's leaders. The fourteenth Torah reading (Exod. 6:2-9:35), wherein Moses and Pharaoh clash in the plague narrative, is developed by the prophecy of Ezekiel against Pharaoh (Ezek. 28:25-29:21), predicting that 'I [God] will make the land of Egypt an utter waste and desolation' (28:10), so that history is set to be repeated. Likewise Jeremiah 46:13-28 is part of Jeremiah's prophecy against Egypt, and it picks up the next Torah reading (Exod. 10:1-13:16), making the original humbling of Egypt into a picture of what is to come in the purposes of God for that troublesome nation. All this shows that the Haftarot reflect a theologically serious handling of Scripture.

Exodus 13:17-17:16 is brought into connection with Judges 4:4$5: 31$, the prose and poetic versions of the story of Deborah, with this section being treated as a parallel to the prose and poetic versions of the Red Sea victory in Exodus 14-15.13 The depiction of God's use of natural forces (especially water) in the Song of Deborah (see 5:4, 21) shows that the Haftarah does not arbitrarily impose an exodus typology upon the passage from the book of Judges. As well, the Song of the Sea foretells the conquest of Canaan (15:15), and the victory of Deborah contributes to its fulfilment. Both inspired songs also feature the chariots and horses of the enemy. Another link is that both Miriam (Exod. 15:20, 21) and Deborah are female prophets. The Haftarah

13 Again the triennial cycle takes a more eschatological interpretation of the material, with the Haftarah chosen for the Seder 56 (Exod. 14:15-16:3) being Isa. 65:24-66:10. In both passages God says he will answer before they cry out for help (Exod. 14:15; Isa. 65:24), and the Red Sea rescue is turned into a rehearsal for the final intervention of God. 
commences, not with a description of the crisis (as does the medieval chapter division at 4:1), but with an introduction of Deborah as a prophetess (4:4), so that this throws emphasis upon her role. The recorded joint-song by Deborah and Barak (see 5:1) becomes a latter-day parallel to the song sung on the shore of the Red Sea by Moses and Miriam. All this suggests that the God of the exodus is still at work in the days of the judges, saving his people and establishing them in the land of promise.

The Torah lesson of Exodus 18-20 about God's manifestation at Sinai is matched by the theophanic vision of Isaiah in the temple (Isa. 6:1-7:6, Ashkenazim; 6:1-14, Sephardim). Fishbane connects Exod. 19:6 to the holiness theme of the Isaianic passage. The addition of Isaiah 9:5-6 (Eng. 9:6-7) by the Ashkenazim suggests a messianic reading, in which the just society of Exodus 18 will only come about through God and the future Davidic king. ${ }^{4}$ The next Haftarah, Jeremiah 34:8-22, 33:25-26 gives a historical example of the infraction of the rule about the release of Hebrew slaves that begins the Torah reading (Exod. 21:1-24:18; esp. 21:1-6). The generation to whom Jeremiah was sent are thereby characterised as lawbreakers. The coda in the form of Jeremiah 33:25-26 implies that only with the restoration of Davidic rule will Israel become a truly just society. In the Parashah, Exodus 25:1-27:19, God commanded the Israelites to build a tabernacle, and the Haftarah describes Solomon's construction of the Jerusalem temple (1 Kgs 5:26 [Eng. 5:12]-6:13), that was meant to be the God-ordained replacement for the tabernacle.

The subsequent Parashah is largely taken up with the garments and ordination of the Aaronic priests, and ends with the command to build an incense altar (Exod. 27:20-30:10), and Ezekiel 43:10-27 gives the blueprint of the sacrificial altar in the new temple and the ordinances for the altar. The parallel paints Ezekiel as a second Moses, with both men being mediators of cultic worship. ${ }^{15}$ The next Parashah (Exod. 30:11-34:35) and Haftarah (1 Kgs 18:1-39) draw a parallel between Moses' dealing with the apostasy of the golden calf and Elijah's confrontation with Baal idolatry at Mount Carmel. 1 Kings 18 depicts a second major crisis that will determine, for good or for ill, the religious future of Israel. Both passages insist on the exclusive worship of the

\footnotetext{
${ }^{14}$ Fishbane, 'Haftarot' 114.

15 Cf. H. McKeating, 'Ezekiel the "Prophet like Moses”?', JSOT 61 (1994): 97-109.
} 
LORD (N.B. the $1 \mathrm{Kgs}$ 18:39 recognition of the LORD as God alone). This is highlighted by $1 \mathrm{Kgs} 18: 39$ being the final verse in the Haftarah. The connection made between Moses and Elijah is by no means arbitrary given the many parallels in the biblical portrayal of these figures. ${ }^{16}$ As well, Ahab is condemned as the most evil Israelite king (1 Kgs 16:30). Ahab walked in the sins of Jeroboam, referring to his setting up the golden calves that was viewed by the writer of Kings as replicating the golden calf declension (1 Kgs 12:28, cf. Exod. 32:4, 8 etc.). Ahab made matters even worse by his marriage to Jezebel who actively promoted Baal worship in Israel.

Bezalel made the tabernacle and its furnishings (Exod. 35:1-38:20) and this is brought into relationship with the work of Hiram of Tyre on the temple, especially bronze pillars and molten sea (1 Kgs 7:13-26). The account of the construction of the temple is deliberately reminiscent of that of the tabernacle (which the pairing of Parashah and Haftarah makes explicit). The last Torah lesson for Exodus (38:2140:38) - the finishing and erection of the tabernacle - is picked up by the account of the completion and dedication of the temple $(1 \mathrm{Kgs}$ 7:51-8:21). In both accounts the theophanic cloud indwells the completed structure. The emphasis upon the building of the temple in the Haftarot prepares for the liturgical focus on its destruction near the end of the annual cycle of readings. The readings for the annual cycle imply (and those of the triennial cycle make explicit ${ }^{17}$ ) that the future glorification of Zion (city and temple) will take place in the plan and purpose of God.

\section{Leviticus}

The lay instructions concerning the five main types of sacrifice (Lev. 1:1-5:26 [Eng. 6:7]) are connected to Isaiah's condemnation of the people for failing to offer these sacrifices and succumbing to the sin of idolatry (Isa. 43:21-44:23). The next Haftarah also raises the question of the attitude of the prophets to Israel's cultic worship, with the reading of the latter part of Jeremiah's temple sermon (Jer. 7:21-8:3,

16 Robert P. Carroll, 'The Elijah-Elisha Sagas: Some Remarks on Prophetic Succession in Ancient Israel', VT 19 (1969): 400-415.

17 The 72nd (Exod. 38:21-39:32) and 73rd Sedarim (Exod. 39:33-40:38) in the triennial cycle are matched by Jer. 30:18-31:8 and Isa. 33:20-34:8 respectively. 
9:22-23 [Eng. 9:23-24]) being the matching reading for Leviticus 6:1 [Eng. 6:8]-8:36, the instructions to priests about the different sacrifices. Outward cultic observance does not make up for the people's disregard for social ethics, with the coda in Jeremiah 9:22-23 [Eng. 9:23-24] reinforcing the divine priority of justice and righteousness.

The deaths of Nadab and Abihu (Lev. 9:1-11:47) and the death of Uzzah (2 Sam. 6:1-7:17) are punishments for the misuse of holy things. David, by way of contrast, is commended for his reverential attitude toward the ark (transferring it to Jerusalem and wishing to house it in a temple structure). Throughout the Haftarot David is seen as an ideal figure and so in effect clothed in a messianic mantle. Both the wider context (Lev. 10:9), and the Haftarah in the triennial cycle (Ezek. 44:21-27; 46:3) for the Seder 80 (Lev. 10:8-20), imply that intoxication contributed to the deaths of Nadab and Abihu (see Rashi's commentary on Lev. 10:2). The intertextual connection may also support an alternate interpretation that goes back to Philo (Laws 2:5758), namely that Nadab and Abihu were insufficiently clad (they had not covered their loins as commanded in Exod. 28:42-43), for Michal criticises David for uncovering himself while transferring the ark to Jerusalem (2 Sam. 6:20). ${ }^{18}$ In the Torah and the Prophetic passages the deaths of the offenders serve as a sober lesson that things must be done exactly as prescribed by God. Uzzah was stuck down because he touched the ark, something that only priests were allowed to do, for it is they who had charge of the furnishings of the tabernacle, the ark included (Num. 3:8; 4:1-20); and there is a reminder in the same context of the fate of Nadab and Abihu (Num. 3:4). In the Haftarah the transfer of the ark to Jerusalem and the building of a temple are not matters for human initiative (though David has the best of motives in proposing these courses of action). Both are unexpectedly interrupted by God to make the point that they must be under his direction.

The next Parashah (Leviticus 12-13) and Haftarah (2 Kgs 4:425:19) deal with the cleansing of lepers, with Elijah's healing of Naaman viewed within the framework of the law that involves washings. Leviticus $14-15$ and 2 Kgs 7:3-20 are thematically connected. Lepers must dwell outside the wilderness camp and the four lepers 'at the entrance to the gate' act to benefit the whole city of

18 See Gershon Hepner, 'Intertextuality and the Haftarot', Judaism 53 (2004), at $<$ http://www.findarticles.com/p/articles/mi_m0411/is_1-2_53/ai_n8964752> (accessed 2 March 2006). 
Samaria, suggesting a compassionate recognition of their place and use in the wider community. The Torah reading, Leviticus 16-18, contains moral and ritual laws that the people of Jerusalem were breaking in Ezekiel's day (Ezek. 22:1-19), so that the prophets are depicted as condemning the people for breaking the law. The laws of Leviticus 1920 reflect the status (and responsibility) of Israel as 'holy' (= chosen; N.B. 19:2; 20:26), but Amos' radical statement appears to relativise God's election of Israel due to their disobedience (Amos 9:7-15, esp. v.7) (Ashkenazim). Both passages, however, see Israel's election as involving moral responsibility. The alternate Haftarah among the Sephardim (Ezek. 20:2-20) makes the same point, with stress upon revering the Sabbath (cf. Lev. 19:3).

Moses' instructions to the priests (Leviticus 21-24) find a parallel in Ezekiel's laws for the Zadokite priests (Ezek. 44:15-31), so that the law was no dead-letter to the prophets. The sabbatical and jubilee laws of Leviticus 25:1-26:2 find a concrete example in Jeremiah's redemption by purchase of family land (Jer. 32:6-27), and his action is made a vehicle for his message of hope for the future. This gives such laws an eschatological dimension. The blessings and curses of the final Parashah for Leviticus (26:3-27:34) are matched by those of Jeremiah in Jeremiah 16:19-17:14, with Jeremiah pronouncing a curse on 'the man who trusts (yibtah) in man' and blessing 'the man who trusts (yibtạh) in the LORD' $(17: 5,7)$. This is certainly an evangelical reading of the law and supports the thesis of H.-C. Schmitt that the Pentateuch is a unified composition focusing on faith as its central theme (GlaubensThematik). ${ }^{19}$

\section{Numbers}

The setting of the wilderness camp (Num. 1:1-4:20) is recalled in Hosea's prediction of a new wilderness period (Hos. 2:1-22 [Eng. $1: 10-2: 19]$ ), when God will 'bring her into the wilderness' and reform Israel anew. ${ }^{20}$ For Hosea the major events of salvation history were to be repeated. Yet we should not infer from Hosea's use of a wilderness

19 'Redaktion des Pentateuch im Geiste der Prophetie', VT 32/2 (1982): 170-89. It is not, however, the root $b$ th h that carries this theme in Pentateuch.

20 The same understanding is reflected in the Haftarah of the triennial cycle (Hos. 2:16-25; Isaiah 35). 
typology that he understood the future as a mere repetition of the past. Rather, he foresaw that Israel's apostasy, which had characterised the former era, would be displaced by a new fidelity in the future. In this way the past becomes a picture of what God will do in the future. ${ }^{21}$ The law for the Nazirite (Num. 4:21-7:89; esp. Numbers 6) provides the background to the annunciation of Samson, for the angel of the LORD announces: 'the boy shall be a Nazirite to God from birth' (Judg. 13:225). Subsequently Samson appears to systematically break all aspects of a Nazirite vow: not avoiding grape products (14:10: 'Samson made a feast [= drinking party] there', cf. Num. 6:3, 4), touching a dead body $(14: 8,9$, cf. Num. $6: 6,7)$ and revealing the secret of his unshorn hair (16:15-17, cf. Num. 6:5). The conjoining of these two passages suggests that we cannot understand the career and failings of Samson without attention to his Nazirite status.

The reading portion Numbers $8-12$ begins with instructions about the seven-branched lampstand (8:1-4), and the matching passage from Zechariah 2:14 (Eng. 2:10)-4:7 features this lampstand in a vision of the two olive trees (= 'the two sons of oil'), who are Zerubbabel and Jeshua. The vision depicts their role in rebuilding the temple. This is another parallel of tabernacle and temple and it indicates that the framers of the Haftarot had an interest in the future (to them) rebuilding of the destroyed temple (post-AD 70). The first (Numbers 13-15) and second (Joshua 2) stories about the spying out of the promised land are linked together, with the good report of the two spies sent by Joshua given in the final verse of the Haftarah (Josh. 2:24). The second time, it is the inhabitants of the land that are fearful. The rebellion of Korah against the leadership of Moses and Aaron (Numbers 16-18) is matched by Samuel's speech in self-defense about the propriety of his leadership (1 Sam. 11:14-12:22).

The defeat of the Amorite kings, Sihon and Og in Numbers 19:122:1 is picked up by the account of the trans-Jordanian campaign and victory of Jephthah (Judg. 11:1-33), and the river Arnon boundary features in both stories. As well, Jephthah's message to the Ammonite king recalls the defeat of Sihon (11:19-23). The omission of the final verses about fate of Jephthah's daughter is deliberate (11:34-40), resulting in a more positive portrait of Jephthah. It is true that $11: 33 \mathrm{~b}$

21 D. R. Daniels, Hosea and Salvation History: The Early Traditions of Israel in the Prophecy of Hosea (BZAW 191; Berlin, New York: Walter de Gruyter, 1990): 117 130. 
('So the Ammonites were subdued before the people of Israel') would make a credible ending to the story of Jephthah, with 11:34-40 having the character of a detachable appendix, but Judges 12:7 is the canonical ending of the account of his judgeship. Closing off the Haftarah at 11:33 also omits mention of the internecine conflict between the Gileadites and Ephraimites that was a further blot upon his judgeship (12:1-6). The positive valuation of Jephthah begins as early as the speech of Samuel, wherein Jephthah is recalled as one of the Godgiven deliverers of Israel (1 Sam. 12:11). The book of Hebrews makes Jephthah out to be one of the heroes of faith (11:32), so that his defects are also downplayed by the New Testament. 1 Samuel 12:11 has clearly influenced the writer of Hebrews, as evidenced by the overlap in names between the two verses. No distortion, intended or actual, takes place in the record of Jephthah's achievement in this exegetical (homiletical) tradition, for the author of the book of Judges takes obvious delight in the exploits its larger-than-life heroes, Jephthah included.

The story of Balak and Balaam (Num. 22:2-25:9) is alluded to in Micah (5:6 [Eng. 5:7]-6:8; esp. 6:5). Balaam's inability to curse Israel is for Micah an illustration of God's saving acts for Israel. The zeal of Phinehas (Num. 25:10-30:1 [Eng. 29:40]) is matched by that of Elijah in the Haftarah (1 Kgs 18:46-19:21; N.B. 19:10, 14). ${ }^{22}$ Both men were used by God to stem the tide of apostasy among the people of God, with the slaying of the apostates a notable feature in both passages (Num. 25:8; $1 \mathrm{Kgs} \mathrm{18:40).}{ }^{23}$ The Haftarot of the last two readings from Numbers (Num. 30:2 [Eng. 30:1]-32:42; 33:1-36:13) and the first reading from Deuteronomy (Deut. 1:1-3:22) are thematically unconnected to the Torah readings. ${ }^{24}$ These are the three sabbaths of admon-

22 Sirach 48:2 speaks of the zeal of Elijah (cf. Sirach 45:23 on Phinehas); and the speech of dying Mattathias to his sons in 1 Maccabees 2 mentions the zeal of both Phinehas and Elijah (vv. 54, 58). These two figures are therefore linked in Jewish tradition.

23 The Haftarah chosen in the triennial cycle to match Seder 121 (Num. 25:10-26:51) is Mal. 2:5-9, suggesting an identification of Malachi's 'the covenant of Levi' with the covenant granted to Phinehas in Num. 25:11-13. The interpretation is disputed by Steven L. McKenzie and Howard N. Wallace, 'Covenant Themes in Malachi', $C B Q 45$ (1983): 549-563, esp. 550.

24 By contrast, the Haftarot for the triennial cycle continue the established pattern of matching in some way (thematic or verbal) the Sedarim of the Torah; e.g. Seder 127 about the distribution of booty (Num. 31:25-53) is connected to Isa. 49:24-26, which speaks of the taking of plunder; in Seder 128 (Numbers 32) the tribes of Reuben and Gad ask for Gilead as their possession, and in the matching Haftarah they take up that possession (Josh. 22:8, 9); the defeat of Sihon and Og, the Amorite kings (Deut. 2:31- 
ition between the seventeenth of Tammuz, anniversary of the breaching of the walls of Jerusalem by the Babylonian army, and the violation of the temple on the ninth of $\mathrm{Ab}$. Their Haftarot are Jeremiah 1:1-2:3; 2:4-28 (Ashkenazim) or 4:1-2 (Sephardim); and Isaiah 1:1-27. All three Prophetic readings with their exposure of the sin of God's people prepare thematically for the reading of the book of Lamentations at the festival.

The next Haftarah (Isa. 40:1-26) is the first of seven weeks of consolation, with all these Haftarot drawn from Isaiah 40-66, though not in the order of the biblical text; namely Isaiah 40:1-26; 49:14-51:3; $54: 11-55: 5 ; 51: 12-52: 12 ; 54: 1-10 ; 60: 1-22 ; 61: 10-63: 9$. These seven weeks assist a transition from grief and repentance to comfort and hope. This amounts to a reinterpretation of Isaiah 40-66 in that these chapters (in context) are not directly related to the destruction of the temple. Certainly the prediction of disaster made in Isaiah 39 has no such focus (see 39:5-7). The rebuilding of the temple is only touched upon in Isaiah 44:28 and 66:1, though the future transformation and glorification of Zion is an important theme in Isaiah 40-66.

\section{Deuteronomy}

The seven readings from Isaiah 40-66 match the seven Torah readings that span Deuteronomy 3:23-30:20. The Haftarah that is assigned to Deuteronomy $31: 1-30$ is also thematically unconnected to the Torah reading as it belongs to the Sabbath of Repentance (Shabbat Shuvah); namely Hosea 14:2-10 and Joel 2:15-27 (Ashkenazim) or Hosea 14:210 and Micah 7:18-20 (Sephardim). Both begin with Hosea's call for repentance. The Parashah consisting of the Song of Moses (Deut. 32:152 ) is matched by a Haftarah that consists of the Song of David (2 Sam. 22:1-51), with both leaders praising God as the 'rock' ${ }^{25}$ The final messianic verse of David's song (22:51) probably influenced the choice of this passage as the final reading from the Prophets, and it gives a messianic slant to the whole reading cycle. The reading of the last two chapters of Deuteronomy are delayed and kept for the holiday

$3: 22$ ) is thematically developed in a series of related prophetic readings (Josh. 10:1213; Hab. 3:11-15; Amos 2:9-10).

25 In the triennial cycle, the Haftarah for Deut. 32 is Isa. 1:2, 3, a Prophetic passage where heaven and earth are called upon to hear an indictment against God's people (cf. Deut. 32:1). 
Simchat Torah, the culmination the festival of Sukkot (Booths), with the matching Haftarah being Joshua 1:1-18. ${ }^{26}$ This shows Joshua taking over from Moses, and the portion has a focus on careful obedience to the Law. The 54 weekly readings thus begin on the sabbath after the feast of Tabernacles and finish on Simchat Torah, that is the feast of the Rejoicing of the Law on the twenty-third day of Tishri.

\section{Summary and Conclusion}

The following may be said by way of summary and conclusion. The Prophetic text chosen usually resembles the Torah reading in some significant and obvious way, as was affirmed in the Talmud (b. Meg. 29b). ${ }^{27}$ The selected Prophetic reading complements the Torah reading; for example, the parallels drawn between the Tabernacle and temple. The connections made between Parashah and Haftarah are not fanciful, but regularly display a sound grasp of the overall intent of the passages connected and suggest an insightful interpretation of the Pentateuchal passage. This is not at all surprising if, as is probably the case, the Haftarot reflect early Jewish exegetical traditions and homilies (either before or after the New Testament era).

The connection between the readings may be a historical parallel, e.g. the two missions of the spies in Numbers 13 and Joshua 2; the Red Sea victory and that of Deborah; the dreams of Joseph and Solomon. More often, however, the parallel is typological (namely a heightened historical repetition), such as the family reunion in Egypt (Genesis 46) becomes a precursor to the ultimate union of north and south predicted by the prophets (Ezek. 37:15-23).

The Haftarah may be given a positive ending by going into the next section (e.g. 2 Sam. 6:1-7:17), or the end of the Haftarah section may interrupt a literary unit, suggesting a new interpretation of the material (e.g. finishing the reading at Judg. 11:33 and so omitting mention of the fate of Jephthah's daughter). An effort is made to end the Prophetic portion on a positive note.

26 The same Haftarah for Deut. 33-34 is used to close the triennial cycle.

27 The example used in b. Megillah 29b is the Haftarah 2 Kgs 12:1-17 (Eng. 11:2112:16) for the supplementary Torah reading for Shabbat Shekalim (Exod. 30:11-16). The Talmud states: 'There is a good reason for the reading Jehoiada the Priest as Haftarah because it is similar in subject.' What is noted is that $2 \mathrm{Kgs}$ 12:5 (Eng. 12:4) alludes to the temple poll tax instituted in Exodus 30. 
The selection of the Haftarah may append verses later in the text (or from another text) to give a more optimistic conclusion, or to shift the meaning from a mundane to a messianic or eschatological level. Examples of such appended verses are Isaiah 9:5-6 (Eng. 9:6-7); 29:22-23; Jeremiah 33:25-26. ${ }^{28}$

There is an overall emphasis upon consolation as opposed to Prophetic critique in the selection of Prophetic portions, though that cannot be construed as optimism about the obedience of God's people. The Prophetic exposure of sin is not ignored and the Israelites are depicted as repeating the sins of their ancestors; for example, Amos' generation is guilty of the same crimes as the patriarchs who sold Joseph (Gen. 37, cf. Amos 2:6).

There is an implicit messianism in the theological emphasis of the Haftarot, given the note on which the Haftarot ends (2 Sam. 22:51), the practice of appending messianic texts to some Haftarot, and the evident interest in finding parallels between the different experiences of David and other Old Testament worthies (Moses, Abraham and Jacob). This, of course, is an attractive feature of the Haftarot for the Christian reader, who has been taught by Jesus himself to seek references to him in the Law and the Prophets (Luke 24:27, 44). The messianism of the Old Testament is not exhausted by a few classic passages in the Prophets (e.g. Isa. 9, 11) and Psalms (e.g. Ps 2, 110). Expectation of a future messianic king (which is what we mean by messianism) is pervasive and can be found in the narratives of the Pentateuch and Former Prophets as well. ${ }^{29}$

The selection of Prophetic portions highlights the reuse of earlier traditions in Prophetic preaching, for example: Abraham in Isaiah 41; Jacob in Hosea 11-12; the wilderness period in Hosea 2; and Micah 6 recalls Balak and Balaam. ${ }^{30}$ This suggests that the framers of the Haftarot saw themselves as following the lead of the Prophetic Books themselves when they detected links between the Torah and prophetic

28 For examples in the triennial cycle, the Haftarah for Seder 4 (Gen. 5:1-6:8) is Isa. 29:18-24, with 30:18 as the appended verse; for Seder 19 (Gen. 22-23) Isa. 33:7-16 are the matching verses, with 33:22 as the appended verse; and for Seder 36 (Gen. 39) the Haftarah is 1 Sam. 2:22-30, with 2:35 as the appended verse.

29 See T. D. Alexander, 'Royal Expectations in Genesis to Kings: Their Importance for Biblical Theology', TynBul 49.2 (1998): 191-212.

30 For the issue generally, see R.E. Clements, Prophecy and Tradition (Growing Points in Theology; Atlanta: John Knox Press, 1975). 
proclamation. They believed that this way of reading Scripture had canonical sanction.

The futility of cultic observance when devoid of ethical concern is exposed in several Haftarot, as reflected in Prophetic denunciation (e.g. Jer. 7; Isa. 43). There is, however, a focus in the Haftarot on temple construction and destruction, and (by implication) its future restoration. The New Testament develops this line of interpretation in a radically different direction than Judaism, with the restoration of the judged temple beginning to take place through the resurrection of Jesus (John 2:12; Mark 14:58; Acts 7:47-50)..$^{31}$

The overall arrangement of matching Parashiyyot and Haftarot suggests that we should understand the books Joshua-Kings as illustrating and applying the theology and ethics of the Pentateuch. ${ }^{32}$ The placement of this canonical block of four books immediately after the Pentateuch also implies that this is their primary function. The coordinating of Torah readings and excerpts from the Latter Prophets (Isaiah, Jeremiah, Ezekiel and the Twelve) turns the prophets into preachers of the Law. The way in which this is done in the Haftarot gives permission for the application of the law to be flexible and contextual. All in all, there is much of value here for the Christian interpreter who is bound by the dominical pronouncement: 'Think not that I have come to abolish the law and the prophets.'

31 See G. K. Beale, The Temple and the Church's Mission: A Biblical Theology of the Dwelling Place of God (NSBT 17; Downers Grove: IVP, 2004).

32 See Arie C. Leder, 'Paradise Lost: Reading the Former Prophets by the Rivers of Babylon', CTJ 37 (2002): 9-27. 